\title{
OBJECTIVE BASIS OF INTERNATIONAL COOPERATION OF THE REPUBLIC OF UZBEKISTAN WITH THE STATES OF SOUTH-EAST ASIA
}

\author{
Guzal Usmanbekovna Sharipova ${ }^{1}$ \\ ${ }^{1}$ VOSIQ International School and Kindergarden \\ Email:guzal.5haripova@yandex.ru
}

\begin{abstract}
This article will expand the horizons of studying political and foreign economic cooperation between the Republic of Uzbekistan and South East Asian countries, in particular with Malaysia, as well as allow studying integration processes of the republic.
\end{abstract}

Keywords: Economics, development, politics, cooperation, growth.

\section{INTRODUCTION}

During the short historical period of Uzbekistan's independent development, a tremendous amount of work has been done to establish the Republic as a sovereign state. Today Uzbekistan is recognized by practically all countries of the world, official diplomatic relations have been established with more than 120 countries.

On a full-fledged basis, Uzbekistan is a member of the most authoritative and influential international organizations, establishing friendly ties with dozens of countries on all continents of the world, closely cooperating with the largest banking and financial bodies, non-governmental organizations. More than 80 foreign representative offices have been accredited in the country, and more than 20 intergovernmental and non-governmental organizations operate. Over the past years, the Republic has acceded to many major international conventions [6].

The successful development of important ties in various areas of international relations is perceived by the Republic as a guarantee of security and stability. Uzbekistan is open to the world and the world has been displaying enormous interest in Uzbekistan, and this is the best guarantee for sustainable development. The state is becoming more and more attractive both from the point of view of investing capital and ensuring security in the region as the main part of comprehensive global security.

Today, all independent nations are addressing the most important tasks - to build a modern democratic state, widely integrated into the world community, which is now becoming multifaceted. The whole world is becoming an integral and interdependent system, with no room for isolation. And this determines the necessity to develop fundamentally new approaches in shaping modern international relations, interaction with international structures and participation in their activities.

\section{MAIN PART}

Strengthening state independence and stability in the region, as well as gaining a worthy place in the world community is the main task of Uzbekistan.

Uzbekistan, which holds a key geopolitical position in Central Asia, is actively cooperating with foreign countries and international organizations.

Aware that integration into the world community is possible provided that it meets the modern concepts of a democratic state with an economically developed market system, Uzbekistan aims to modernize the country and take a worthy place in the international division of labor, to actively participate in creating systems of regional and global security of the nation.

Over the years of independence, Uzbekistan has established diplomatic, economic and cultural relations with many countries of Europe, America, East and Southeast Asia: with South Korea, Indonesia, Japan and Malaysia, which clearly confirms the growing interest in our republic and their participation in addressing a range of complex problems in our region. Uzbekistan remains true to the principles of 
humanism and openness and mutual respect in its foreign policy, and relies on its own strength and its own path of development.

The strategic partnership of Uzbekistan and Central Asian countries with Russia, China, USA, Japan, as well as cooperation with such major international and regional organizations as UN, EU, UNESCO, OSCE, NATO, CIS and SCO, contribute to the social, economic, spiritual and intellectual development of the republic and the solution of pressing problems in Central Asia [3].

Of particular interest to the development of our republic's integration processes are its relations with the countries of the South East region.

The period of independent development in the history of South East Asian states (SEA) starts at different times. For Indonesia, Burma (Myanmar), the Philippines, and northern Vietnam it began in the first years after the end of World War II. For Laos, South Vietnam and Cambodia in 1965, for Malaysia in 1957, for Singapore in 1965 (from 1959 to 1965 it was a federation of Malaysia), and for Brunei since 1984 $[5 ; 215]$.

Naturally, such an uneven line of political development of the South East Asian states has affected both the domestic policy of each country individually and regionally. The division of the region into two parts - the states of Indochina and the rest of the countries, most of them in the Association of Southeast Asian Nations (ASEAN) established in 1967 [5; 217] - can be quite clearly drawn.

ASEAN is made up of Indonesia, Malaysia, Singapore, Thailand, the Philippines and Brunei. It is a subregional, political and economic organization whose official goals are to develop economic, social and cultural relations among its member countries, promote peace and stability in South-East Asia and maintain cooperation with international organizations. Work is under way in ASEAN to implement joint industrial projects. The member countries of the Association actively support the neutrality of South East Asian states and struggle for the transformation of their region into a nuclear-free zone [5;226].

Various international regional cooperation projects, including those of ASEAN, are very beneficial and of great benefit to Central Asia. In our interview and sociological survey of experts and officials from the Central Asian Republics, Russia and the United Kingdom in 2006-2007, a large number of specialists (95\%) consider ASEAN as good models for regional integration in Central Asia along with the EU [4].

The governing body of ASEAN is the annual conferences of foreign ministers, which are held alternately in the capitals of the participating countries. In between sessions, there is a Standing Committee, under the representation of the Minister for Foreign Affairs of the country where the next conference is scheduled to take place, and consisting of ambassadors from other member countries of the association accredited in that country. Its headquarters are located in Jakarta, Indonesia.

In the second half of the twentieth century, the states of Indochina, which made up French Indochina, tested in practice different models of socialist development, which lasted until 1975, in the 90s, the countries to varying degrees, also integrated into ASEAN, conducting a course in the economy to develop market relations. Therefore, since the end of the decade, we can talk about the common destinies of all ten states in the region.

The situation in the South East Asia region at the end of the twentieth and beginning of the twentyfirst century is quite diverse and controversial, too many specific features are revealed in it. Of these, one is more interesting than the others in terms of structure. It is that East Asia today remains the only region in the world where the economic type of regulation of international relations clearly continues to prevail, while at the global level, as well as at the level of the European and Central Eurasian subsystems of international relations, there are all signs of a crisis of world regulation, the most important manifestations of which are -

First, there has been a massive increase in regional conflict;

Secondly, the ineffectiveness of existing mechanisms for peaceful settlement;

Third, a peculiar "backward growth" of the value of military force as an undesirable, but often the only possible means of restraining "scattered" instability.

It is this trait - the preservation of the economic dominance of regional relations and the absence of a visible increase in the military factor - that seems to predetermine the success of the rebirth of the East Asian structure of relations from leadership to space. South East Asia - simply by inertia or due to a more flexible, mobile and stable stability structure that has been established here - continues to be dominated by the tendency to economize regional life, which has been in place since the second half of the 1970s, when 
the central problem of bipolar confrontation was inter-block competition for economic supremacy. It was against the backdrop of the easing of the "military alarm" after the end of the Cold War that the Asia-Pacific Region (APR) experienced accelerated economic development. In 1989-1993, Japan, for example, was ahead of all developed countries in terms of the WEP growth rate of $2.7 \%$. The US GNP grew by $1.7 \%$ in the same years (for comparison: the average for France for the same period was $1.5 \%$ and for the UK only $0.3 \%$; the German economy grew even slower after the unification). At the same time, the GNP of China increased on average by $8.6 \%$, South Korea by $7.1 \%$, Taiwan by $6.5 \%$ of ASEAN countries by $6.7 \%$ [1].

Obviously, based on outpacing economic growth, developing countries (the INES-South Korea, Taiwan, Hong Kong and Singapore - and later on the last ASEAN member state) have started to play an increasingly prominent role in economic processes and have significantly strengthened their positions in the economic life of East Asia and the world economy as a whole. As development progressed, young nations began to perceive both the overall balance of power in the regional situation and their own role in it in a significantly different way. The main psychological outcome of the 1980s in this sense was that the developing country became convinced of its ability, without entering into conflict with the leaders, to force them, including the United States and Japan, to take into account the views and interests of small states through "passive resistance" methods and without taking drastic diplomatic or political steps. In other words, small and medium-sized countries, among which the tone was set by ASEAN states without opposing themselves to the stronger players, while at the same time, through repeated but delicate refusals to build regional economic and political cooperation on U.S. or Japanese terms, eventually imposed their logic of consensual engagement on leaders, which, with objectively unequal opportunities for leaders and "space countries", "actually meant concessions by the former in favor of the latter. In fact, the United States attempted for the first time in the post-war years to fit "into the logic and structure of a purely "spatial" relationship" that had actually emerged and established itself without participation and in part contrary to Washington's opinion.

On a structural level, it was a significant shift. By the early 1990s, the Asia-Pacific Region actually had two interacting but largely autonomous sets of interstate relations based on the principle of dynamic stability. The first was the Japanese-American partnership. The second was cooperation among ASEAN countries. Moreover, the relations between the two complexes were built on a substantially different logic than the relations within each of them. Increasingly dependent on each other, the United States and Japan sought to find a way to make mutual concessions for the sake of accelerated development. Similarly, the ASEAN states, by creating the fragility of the positions of each of them separately, tried to overcome their endless disputes and contradictions within the framework of solidarity and unity, even if the immediate interests of individual countries were not fully realized.

\section{CONCLUSION}

World civilization and cultural development, as we see it, is not possible without the development of international relations. It should be noted that the strengthening of state independence stability in the region, peaceful foreign policy of our state and its desire to develop close cooperation in foreign policy was reflected in the resolution of the President of the Republic of Uzbekistan "On measures to further expand cooperation with the leading states and regional organizations of South and Southeast Asia" [6].

It allows to activate the whole complex of political, trade and economic, investment and humanitarian ties with the leading states and regional organizations of South and Southeast Asia.

\section{REFERENCES}

[1] Bogaturov A.D. Great Powers in the Pacific Ocean. 1997. [Bogaturov A.D. Velikie derzhavy na Tihom okeane.M., $1997 g 89$ str.].

[2] Decree of the President of the Republic of Uzbekistan dated 12.08.2005 N PP-156 "On measures to further expand cooperation with leading states and regional organizations of South and Southeast Asia in 2005-2007". [Postanovlenie Prezidenta Respubliki Uzbekistan ot 12.08.2005 g. N PP-156 "O merah po dalnejshemu rasshireniyu sotrudnichestva s vedushimi gosudarstvami i regionalnymi organizaciyami Yuzhnoj i Yugo-Vostochnoj Azii v 2005-2007 gg."].

[3] Mirzokhid R. International cooperation of Uzbekistan in the context of ensuring stability and sustainable development in Central Asia. T., 2011. 6 p. [Mirzohid R. Mezhdunarodnoe 
sotrudnichestvo Uzbekistana $v$ kontekste obespecheniya stabilnosti $i$ ustojchivogo razvitiya $v$ Centralnoj Azii. T., 2011. 6 str.].

[4] Rahimov M. From Soviet republics to independent states: Challenges of transition in Central Asia// in the Greater Middle East in Global Politics: Social Science Perspectives on the Changing Geography of the World politics. by Mehdi Parvizi Aminech(ed.) Brill Academic Publishers (Leiden and Boston). 2007. Pp. 279-300.

[5] The Newest History of Asian and African Countries of the 20th Century P.2. edited by A.M. Rodriguez. M., 2003.215 -226 pp. [Novejshaya istoriya Stran Azii i Afriki XX vek Ch.2. pod red A.M Rodrigesa. M.,2003.215 -226 str.].

[6] Tyurikov V., Shagulyamov R. On the way to independence. T., 2000. [Tyurikov V., Shagulyamov R. Po puti nezavisimosti. T., 2000].

[7] Irgashevich, D. A. (2020). Development of national network (tas-ix). ACADEMICIA: An International Multidisciplinary Research Journal, 10(5), 144-151. Article http://dx.doi.org/10.5958/2249-7137.2020.00254.2 